\title{
Ethical Issues in Disaster Management
}

\author{
Kubilay Kaptan ${ }^{1, *}$ \\ ${ }^{1}$ Beykent Üniversitesi, Inşaat Mühendisliği Bölümü, Istanbul.
}

\begin{abstract}
The predictions related to earthquakes have drawn the attention of society as well as media in the developing countries where the 'common' people have different perceptions. Most often, popular myths take over scientific facts among the public, and this can lead to rumors about natural hazards. This article will mention rumors related to natural disasters, and particularly the rumors regarding the response of society, media and government when earthquakes happen. This research emphasizes the ethical responsibility needed to be undertaken by scientists to avoid panic instead of the rumors by pseudo-experts. This article summarizes the efforts provided by the scientists to prevent the recent rumors about a sudden water rise in Lake Van, the flash flood occurred in the Samsun Province and the earthquake happened (M 6.7, October 23, 2011) in the Van Province in Turkey.
\end{abstract}

$\underline{\text { Keywords }}$

Ethic, Natural Hazards, Disaster Management, Ethical Issues

\section{Afet Yönetiminde Etik Sorunlar}

\section{Özet}

Depremle ilgili tahminler insanların farklı algllara sahip olduğu gelişmekte olan ülkelerde toplumun dikkatinin yanı sıra medyanın da dikkatini çekmiş durumdadır. Çoğu zaman, toplumda halk efsaneleri bilimsel gerçeklerin yerini alabilmektedir ve bu durum doğal afetler hakkında söylentilere yol açmaktadır. Bu makale doğal afetler ile ilgili söylentiler ve özellikle deprem durumunda toplum, medya ve hükümetin tepkisi hakkında söylentilere değinecektir. Bu araştırma sözde uzmanlardan kaynaklanan söylentiler yerine bilim insanlarının paniği önlemek için üstlenmeleri gereken etik sorumluluğa dikkat çekmektedir. Bu makale, Türkiye'de, Van Gölündeki ani yükselme, Samsun Illinde meydana gelen ani sel ve Van'da gerçekleşen deprem (M 6.7, 23 Ekim 2011) ile ilgili söylentileri gösterip, Bilim İnsanlarının bu söylentileri önlemek için ortaya koyduğu çabaları özetleyecektir.

\section{$\underline{\text { Anahtar Sözcükler }}$}

Etik, Doğal Afetler, Afet Yönetimi, Etik Sorunlar

\section{Introduction}

In any profession, a basic set of moral values needs to be followed to comply with what we call ethics. Geoscientists have significant roles to play, more particularly in the field of geohazards, to appraise society about the possibilities of natural hazards such as landslides, avalanches, floods, volcanoes, and earthquakes. Geoscientists cannot only assess these hazards, but they can also estimate the potential consequences if these hazards occur in a given place and at a given time. However, sometimes it has been found that the credibility of geoscientists among society and government is lost, due to some unethical practices for short term gain, or due to incorrect understanding of geological phenomena.

Professional culture and ethics are very important issues for credibility, sustenance and development of any subject, particularly those related to societal, humanitarian and environmental aspects (Bar-On et al. 2013; Cohen et al. 2014). Geosciences have contributed a lot to our understanding of the Earth and how to use it as a resource for human development. The applied branches of geosciences, including for example mining geology, engineering geology, hydrogeology, environmental geology and economic geology, use geoscientific knowledge and information for the exploration and exploitation of the natural resources of the Earth, as well for the reduction and management of geo-risks (Timbie et al. 2013). This article mainly discusses the issues related to geoscientific culture and ethics in disaster management, with some case examples from landslides, debris flows, flash floods and earthquakes in different parts of Turkey.

\section{Case Studies on Earthquake Disasters}

An earthquake of magnitude 6.7 struck the Van Province in the eastern part of Turkey at about 13:41 hours on October 23, 2011, with the epicentre near the Ercek Lake (Report on Van Earthquake 2011). The author had the opportunity to 
visit the affected area soon after the earthquake, for monitoring of the response and to carry out a quick reconnaissance of the damage/losses through a field survey. The earthquake had caused the death of about 644 people and the economic loss of approximately 555 million USD to 2.2 billion USD (CEDIM Forensic Earthquake Analysis Group 2011). During the survey, the author received information from the media and administrators in the affected area about some reports of lake outburst floods in the higher reaches of Van Province that were yet not accessible (Figure 1). The reports also indicated that some people were also suspicious about landslide activities in the area after the earthquake. These reports created great panic among the public, as well as the State administration. The author gathered the necessary information about the geology and geomorphology of the area, and confirmed that these reports were just rumors.

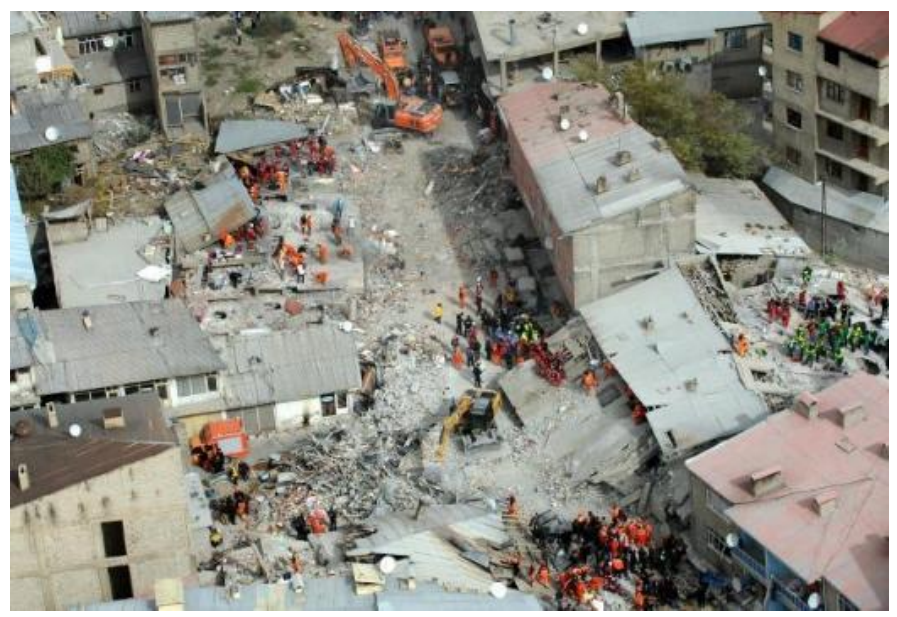

Figure 1: Van Earthquake, Turkey, 2012.

This professional geoscientific information helped to build confidence among the State administrations and to dispel rumors about the phenomenon. The author participated in the meetings of non-governmental organizations, media and government officials at the emergency operation center of the State, to inform all concerned about the real situation in the field based on geo-scientific knowledge of the area. Thereafter, the response teams for post-earthquake activities planned their operations appropriately in the affected areas.

Geologists have had important roles in society by identifying earthquake prone areas through correct mapping and by assessing the possibilities of major earthquakes based on geo-tectonic and seismological studies. However, the views of geoscientists were shattered when an earthquake of magnitude $>6$ occurred in Adana, Turkey, in 1998. The area had been declared a low seismic activity zone, as it formed a part of Turkey that was considered to be relatively stable in geological terms, in comparison to other areas.

The credibility of the seismic zonation map as well as the geoscientific views about spatial prediction of earthquakes was challenged by the Adana earthquake, and later led to the revision of the seismic zonation of map of Turkey. The four seismic zones in the Turkey map have been determined in 1998 (Figure 2).

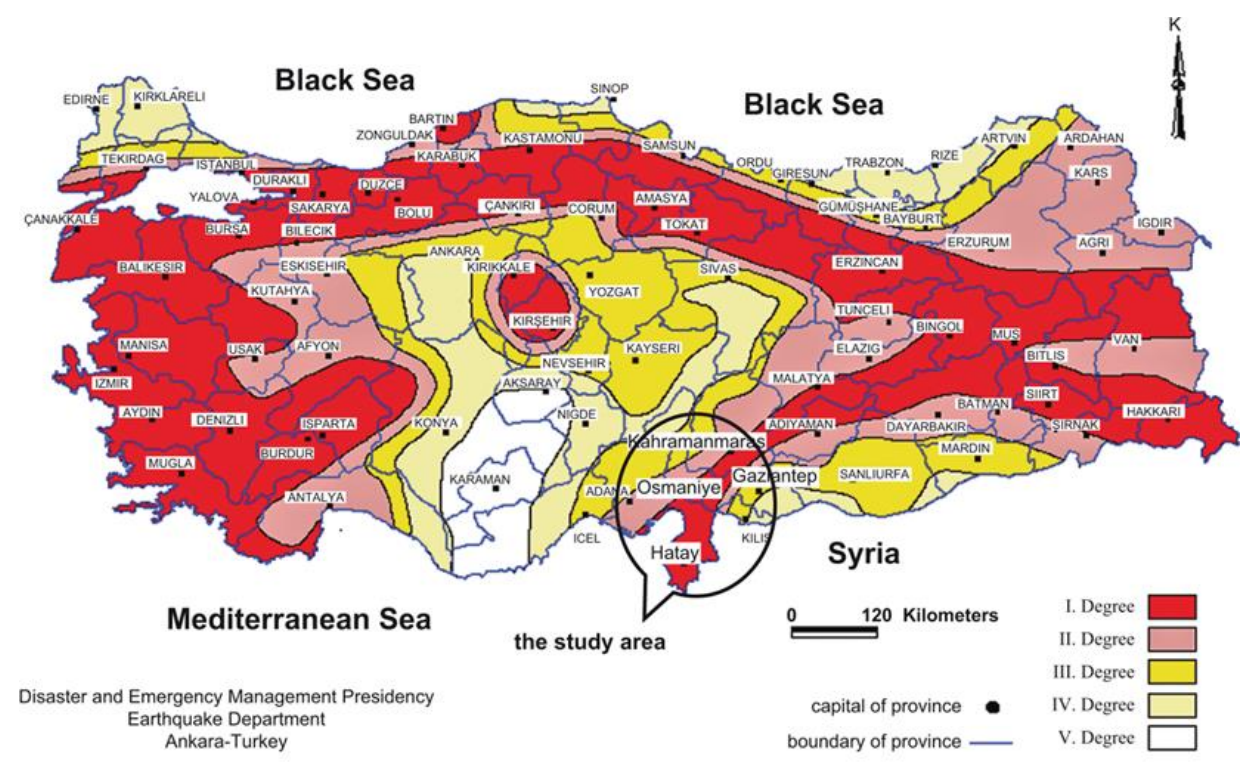

Figure 2: Seismic Zone Map of Turkey, 1998. 
However, the author's personal opinion related to geoscientific culture and ethics for disaster management is not very encouraging as he finds a gap in field mapping of the related features for seismic zonation and inadequate seismic instrumentation. Therefore, to build greater confidence among society regarding geoscientific practices, we must make our claims about earthquakes on the basis of systematic field mapping and instrumental records (Finestone et al. 2014).

However, it would be worthwhile to mention here that there have been some instances where some geoscientists have made wrong predictions about earthquakes and have communicated the same to the public through the mass media, which has resulted in panic and chaos. Later, these scientists even had to face the fury of the people and other members of the geoscientific community (Anthony et al. 2010). One of these examples can be cited from Istanbul in northern Turkey, where a scientist predicted the occurrence of a major earthquake during a specific period, although nothing happened. The tribal people of the area were unhappy over such an incredible warning, and threatened the scientist not to repeat these kinds of false warnings among the public (Corn et al. 2014; Clover et al. 2014).

\section{Case Studies on Debris Flows and Landslides}

Samsun in the north part of Turkey was severely affected by cloud-burst induced debris flows in July 2012. The debris flows led to the loss of 13 people and an economic loss of more than 150 million USD, due to damage to buildings and infrastructure (Figure 3).

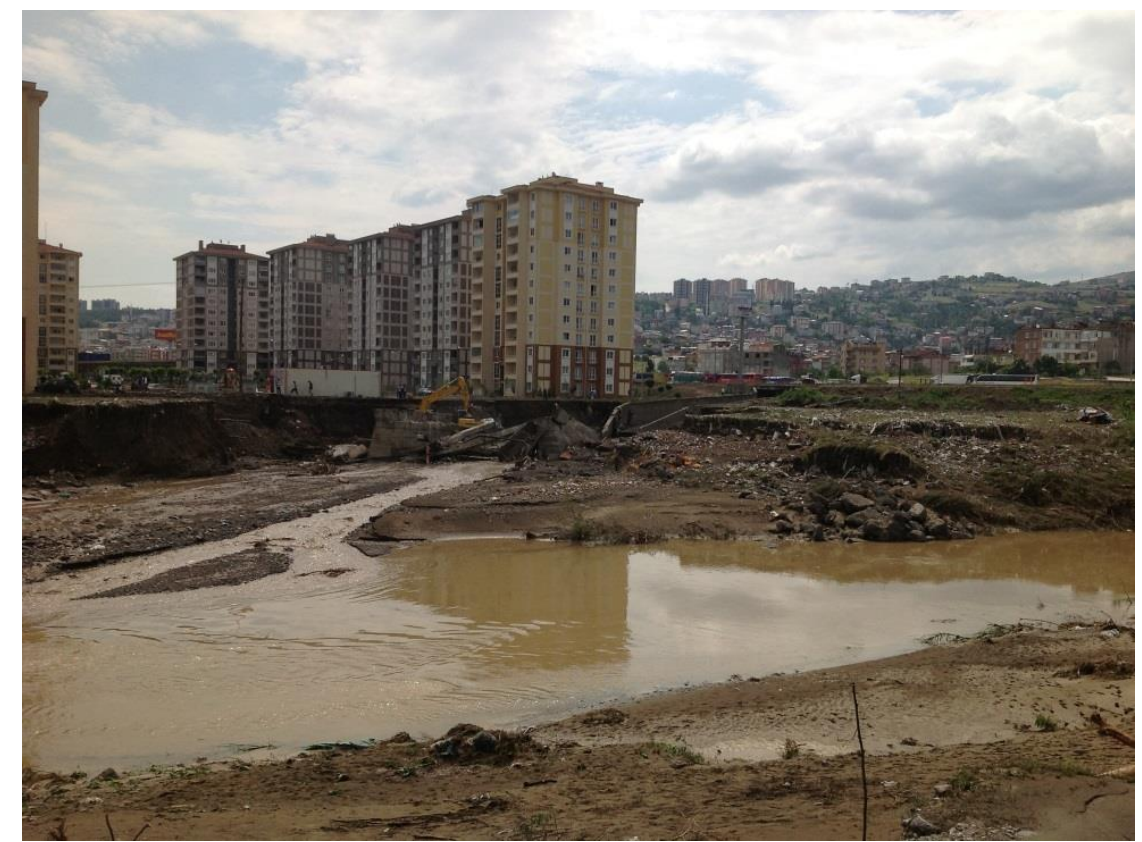

Figure 3: Samsun Flood, 2012.

The author visited the affected area soon after the disaster and interacted with the local community as well as the administration. Samsun is part of a rainy area with a rainfall (less than $700 \mathrm{~mm}$ per annum), although during July 2012 , the area was suddenly hit by $900 \mathrm{~mm}$ to $1050 \mathrm{~mm}$, leading to huge debris flows in the area. The river basin at the area was recently rehabilitated and buildings were constructed at the area. The heavy precipitation during July 2012 was considered to be due to the rehabilitation of the rivers, which resulted in micro-climatic changes. So, a negative opinion about the rehabilitation program arose among the public (Hung et al. 2013; Ben-Ezra et al. 2013). The author made detailed observations in the area and found that although changes in precipitation amounts were possibly due to microclimatic changes, the damage/losses due to rain-induced debris flows were mainly caused by a poorly constructed dam above the city (Miskin et al. 2010). This dam burst and brought huge amounts of debris on the downstream sides, causing loss of human lives and property (Figure 4).

In March 2010, the author came across another landslide in the Karakocan District of Elazı̆g in east of Turkey. The landslide took place due to M6 earthquake and engulfed a village, as well as damaging roads and other infrastructure (Figure 5). The author heard a rumor from local officials that the landslide was triggered by an explosion of gas inside the rock, or some volcanic activity. These myths override people's sentiments or minds, and gain ground if not properly dealt with by the geoscientific community. It was chance that the author had studied this area for landslide problems earlier and had identified this particular site as a potential landslide area based on the terrain characteristics. He informed the public and the local administration that the information about the underground gas explosion or volcanic activity was not true, as the local geology and geo-tectonic activities did not favour the occurrence of these phenomena. Rather, it was a case of a landslide and rockfall, due to a moderate earthquake. 


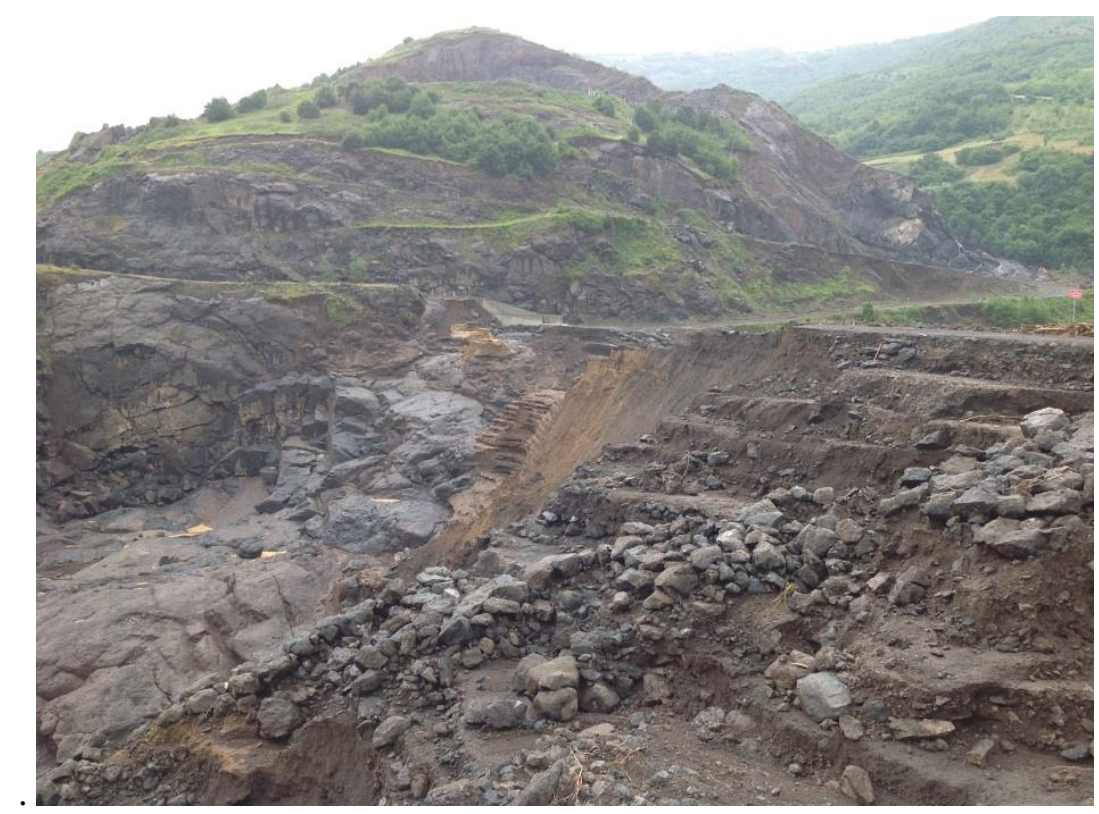

Figure 4: Partially Collapsed Dam at Samsun Flood, 2012.

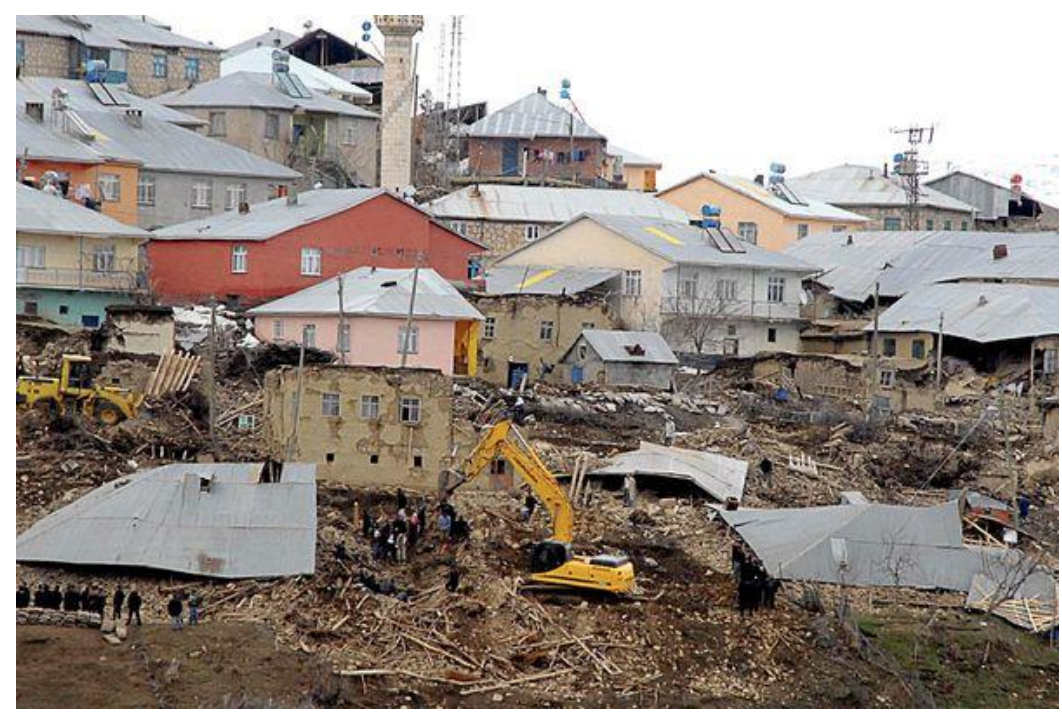

Figure 5: Elazığ Landslide, 2010.

The other major issue found in ethical practices related to geohazards was the gap in communicating relevant information and reports to the authorities concerned by the geoscientists, as well as getting them to understand the phenomena. The area was surveyed by the Geological Survey of Turkey, and a report about the possibility of landslides was given to the administration prior to its occurrence. This was why people were evacuated and lives were saved. However, it did not help the administration to understand the phenomenon well. The author used his reports of previous studies in the area, and made the factual situation at the site clear. The author was also contacted by the media, and the correct information was shared with the public through print and electronic media.

\section{Conclusions}

It can be concluded from the above case studies and discussion that the geoscientific community have a very important role to play in the field of geohazards risk management; however, it requires hard work, sincerity and honesty for ethical practices, and to maintain the credibility of this profession among the 'masses'. There might be some cases where accurate knowledge or information is not available to geoscientists due to indeterminacy or uncertainties in the nature of a geohazard, so we should then be cautious to provide our input within the given limitations.

The strength of a geoscientist lies in the correct understanding of the Earth's environment and processes, including the role of humans in causing and controlling adverse consequences of geohazardous events, like earthquakes, 
landslides, volcanic activity, and tsunamis. It would be good if the appropriate standards of practices in geo-sciences can be followed, to achieve credible and reliable results with more accurate information. The knowledge and information thus generated should be well validated through field checks and discussions among the geoscientific community, before they are shared with others.

Geoscientists should gear themselves up for a better understanding of the geohazards and for disaster-risk management. Critical assessments and evaluations should be done in the positive as well as negative roles played by geoscientists in disaster management, to improve our practices and eliminate our shortcomings.

\section{References}

Anthony S., Colleen B., Michel O., Landry D., (2010), Spinal Cord Injury in Postearthquake Haiti, Lessons Learned and Future Needs, PM\&R 2, 695-697.

Bar-On E., Lebel E., Blumberg N., Saqi R., Kreiss Y., (2013), Pediatric orthopedic injuries following an earthquake, Journal of Trauma and Acute Care Surgery, 74(2), 617-621.

Ben-Ezra M., Palgi Y., Hamama-Raz Y., Soffer Y., Shrira A., (2013), Against all odds: a preliminary study comparing hospital personnel and rescue personnel reactions to Haiti's earthquake, General Hospital Psychiatry, 35(1), e1-e2.

CEDIM Forensic Earthquake Analysis Group, (2011), Comparing the current impact of the Van Earthquake to past earthquakes in Turkey, Center for Disaster Management and Risk Reduction Technology (CEDIM), Istanbul, Turkey.

Clover B., Jemec A., Redmond D., (2014), The Extent of Soft Tissue and Musculoskeletal Injuries after Earthquakes Describing a Role for Reconstructive Surgeons in an Emergency Response, World Journal of Surgery 38, 2543-2550.

Cohen I., Mandelbaum A., Zychlinski N., (2014), Minimizing mortality in a mass casualty event: fluid networks in support of modeling and staffing, IIE Transactions 46, 728-741.

Corn B.W., Symon Z., Gamzu R., (2014), The State of Radiation Therapy in the State of Israel, International Journal of Radiation Oncology*Biology*Physics, 90(5), 975-978

Report on Van Earthquake, (2011), Disaster and Emergency Management Presidency, Earthquake Department, Ankara, Turkey.

Finestone A.S., Levy G., Bar-Dayan Y., (2014), Telecommunications in Israeli field hospitals deployed to three crisis zones, Disasters, 38(4), 833-845.

Hung K.K., Lam E.C., Chan E.Y., Graham C.A., (2013), Disease pattern and chronic illness in rural China: The Hong Kong Red Cross basic health clinic after 2008 Sichuan earthquake, Emergency Medicine Australasia, 25(3), 252-259.

Miskin I.N., Nir-Paz R., Block C., Merin O., Burshtein S., Pirogovsky S., Halperin T., Schwartz D., Schwaber M.J., (2010), Antimicrobial Therapy for Wound Infections after Catastrophic Earthquakes, New England Journal of Medicine, 363(26), 25712573.

Shiloh A.L, Savel R.H., Leung S., Carlese A.J., Kvetan V., (2011), Mass Critical Care, In: Textbook of Critical Care: Expert Consult Premium Edition, (Vincent J.L., Abraham E., Kochanek P., Moore F.A., Fink M.P., Ed.), Elsevier Saunders, Philadelphia, ss.1633-1645.

Timbie J.W., Ringel R.S., Fox D.S., Pillemer F., Waxman D.A., Moore M., Hansen C.K., Knebel A.R., Ricciardi R., Kellermann A.L., (2013), Systematic Review of Strategies to Manage and Allocate Scarce Resources During Mass Casualty Events, Annals of Emergency Medicine, 61(6), 677-689. 